\title{
Two mutations of the Gs $\alpha$ gene in two Japanese patients with sporadic pseudohypoparathyroidism type la
}

\begin{abstract}
Pseudohypoparathyroidism Ia (PHP-Ia), is an inherited disease with clinical hypoparathyroidism caused by parathyroid hormone resistance (PTH), and shows the phenotype of Albright hereditary osteodystrophy (AHO), including short stature, obesity, round face, brachydactyly, and subcutaneous ossification. This disease is caused by mutation that inactivates the $\alpha$-subunit of Gs, the stimulatory regulator of adenylyl cyclase. Here, a novel frameshift mutation (delG at codon 88) in exon 4, and a missense mutation $(\mathrm{R} 231 \mathrm{H})$ in exon 9 of the $G s \alpha$ gene were identified in two Japanese patients with sporadic PHP-Ia. Deletion of a $\mathrm{G}$ in exon 4 at codon 88 in the first patient produced a premature stop codon, resulting in the truncated protein. The second patient had a previously reported $\mathrm{R} 231 \mathrm{H}$ mutation. Because this amino acid is located in a region, switch 2 , that is thought to interact with the $\beta \gamma$ subunit of $G s \alpha$ protein, this mutation may impair Gs protein function. We report here one novel Gs $\alpha$ mutation, and note that mutations in Japanese patients with PHP-Ia are probably heterogeneous.
\end{abstract}

Key words Pseudohypoparathyroidism Ia (PHP-Ia) . Albright hereditary osteodystrophy (AHO) · Parathyroid hormone $(\mathrm{PTH}) \cdot$ Hypothyroidism $\cdot G s \alpha$ gene $\cdot$ Deletion mutation

Y. Ishikawa $\cdot$ T. Nagashima

Department of Pediatrics, Kushiro Red Cross Hospital, Kushiro, Japan

T. Tajima $\cdot$ J. Nakae $\cdot$ K. Satoh $\cdot$ K. Okuhara $\cdot$ K. Fujieda ${ }^{1}(\square)$ Department of Pediatrics, Hokkaido University School of Medicine, Sapporo, Japan

Present address

${ }^{1}$ Department of Pediatrics, Asahikawa Medical College, 2-1-1-1

Midorigaoka, Higashi, Asahikawa 078-8510, Japan

Tel. +81-166-68-2480; Fax +81-166-68-2489

e-mail: ken-fuji@asahikawa-med.ac.jp

\section{Introduction}

Pseudohypoparathyroidism (OMIM number, 300800) is an inherited disorder, caused by resistance to parathyroid hormone (PTH). This disorder is classified into three subtypes according to cyclic (c)AMP response to PTH and somatic features. PHP-Ia shows impaired cAMP response and the features of Albright's hereditary osteodystrophy (AHO), including short stature, obesity, round face, brachydactyly, and subcutaneous ossification. Furthermore, resistance to multiple adenylyl cyclase stimulating hormones, including thyroid-stimulating hormone (TSH) and gonadotropins, is also frequently observed. PHP-Ib shows only PTH resistance, in the absence of any somatic features of AHO; whereas the term "pseudo-PHP (PPHP)" is used to describe the sole occurrence of the somatic features of AHO without PTH resistance (Farfel et al. 1980; Levine 1999; Spiegel 1999).

A variable reduction in the activity of the alpha subunit of the stimulatory form of the GTP-binding protein $(G s \alpha)$ has been demonstrated in the majority of PHP-Ia and PPHP patients (Levine 1999; Spiegel 1999), and heterozygous loss-of-function mutations of the Gs $\alpha$ gene have been described (Fig. 1) (Ahmed et al. 1998; Farfel et al. 1996; Fischer et al. 1998; Iiri et al. 1994; Miric et al. 1993; OudeLuttikhuis et al. 1994; Pattern et al. 1990; Schwindinger et al. 1994; Shapira et al. 1996; Warner et al. 1997, 1998; Weinstein et al. 1990, 1992; Yu et al. 1995, 1999). The widespread deficiency of Gs protein can explain the resistance to PTH and other hormones whose receptors are coupled to Gs; however, the relationship between AHO phenotypes and $G s \alpha$ mutations remains unclear.

In contrast, PHP-Ib is not associated with a reduction in $G s \alpha$ activity, and there is general agreement that PHP-Ib is not caused by this defect.

Regarding the inheritance of PHP-Ia and PPHP, it has been proposed that, when the mutated paternal allele is inherited, offspring will show a PPHP phenotype, whereas, when the mutated maternal allele is inherited, clinical and biochemical characteristics of PHP-Ia will be present 


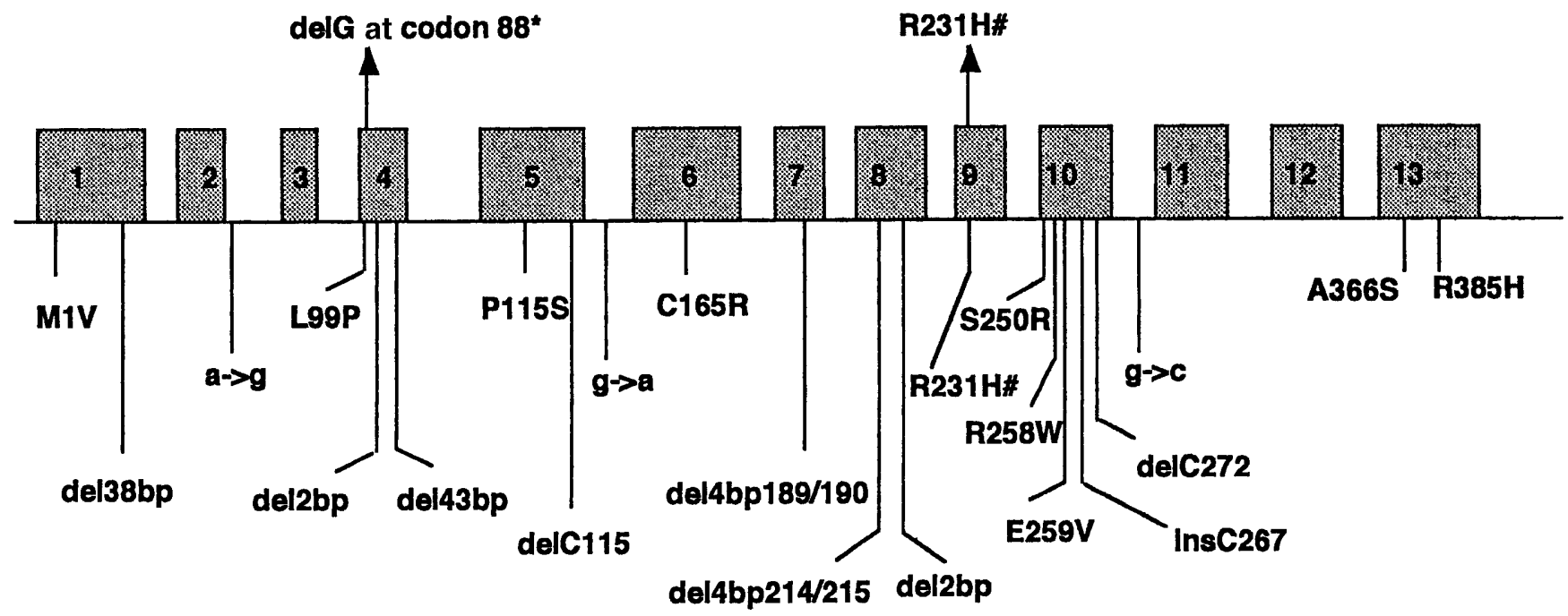

Fig. 1. Schema of the $G s \alpha$ gene and its mutations in pseudohypoparathyroidism Ia (PHP-Ia). Shaded boxes indicate the exons of the $G s \alpha$ gene. Missense, splice, and frameshift mutations are shown. Previously reported mutations are displayed below the schema for the Gsa gene, and the two mutations identified in our study are displayed above. Asterisk indicates the novel mutation. The R231H

(Hayward et al. 1998; Marguet et al. 1997; Nakamoto et al. 1998; Wilson et al. 1994). Moreover, a mouse study demonstrated that only the maternaly transmitted allele of the $G s \alpha$ gene was expressed in renal medulla (Weinstein et al. 2000). These findings strongly support the idea that $G s a$ could be an imprinting gene.

Here, we describe a novel frameshift mutation in exon 4 of the $G s \alpha$ gene, as well as a previously reported missense mutation $(\mathrm{R} 231 \mathrm{H})$ in exon 9, in two Japanese patients with sporadic PHP-Ia.

\section{Case reports}

\section{Patient 1}

The patient is a 7-year-old Japanese boy. His parents were divorced, and he has now been adopted, so it was difficult to obtain his exact family history. At the age of 6 years, he developed grand mal seizures and was referred to our clinic. At that time, his serum calcium level was low $(4.1 \mathrm{mg} / \mathrm{dl}$; normal range, $8.8-9.5 \mathrm{mg} / \mathrm{dl}$ ) and serum phosphate was high $(9.5 \mathrm{mg} / \mathrm{dl}$; normal range, $4.5-6.0 \mathrm{mg} / \mathrm{dl})$ (Table 1$)$. He showed the typical features of AHO, including brachydactyly, round face, short stature $(108.5 \mathrm{~cm},-2 \mathrm{SD}$ for a normal Japanese boy), and obesity (body weight, $24.5 \mathrm{~kg}$ ). His mental development was mildly retarded. His serum intact PTH level was very high $(360 \mathrm{pg} / \mathrm{ml}$; normal range, $13-53 \mathrm{pg} / \mathrm{ml})$ (Table 1). To analyze PTH resistance, we performed a bolus injection of PTH-(1-34) and measured urinary phosphate and cAMP concentrations. As shown in Table 1, urinary cAMP and phosphate did not increase after PTH stimulation. His serum basal thyroid stimulating hormone (TSH) mutation was reported previously (Farfel et al. 1996). Data for mutations were derived from the following references (Ahmed et al. 1998; Farfel et al. 1996; Fischer et al. 1998; Iiri et al. 1994; Miric et al. 1993; Oude-Luttikhuis et al. 1994; Pattern et al. 1990; Schwindinger et al. 1994; Shapira et al. 1996; Warner et al. 1997, 1998; Weinstein et al. 1990, 1992; Yu et al. 1995, 1999)

Table 1. Biochemical and endocrinological data

\begin{tabular}{|c|c|c|}
\hline & Patient 1 & Patient 2 \\
\hline $\begin{array}{c}\text { Serum Ca (normal range, } \\
8.8-9.5 \mathrm{mg} / \mathrm{dl} \text { ) }\end{array}$ & 4.1 & 6.1 \\
\hline $\begin{array}{l}\text { Serum P (normal range, } \\
4.5-6.0 \mathrm{mg} / \mathrm{dl})\end{array}$ & 9.5 & 7.3 \\
\hline $\begin{array}{l}\text { Serum PTH }(\mathrm{pg} / \mathrm{ml})(\text { normal } \\
\text { range, } 13-53 \mathrm{pg} / \mathrm{ml})\end{array}$ & 360 & $523^{\mathrm{b}}$ \\
\hline \multicolumn{3}{|l|}{ PTH-(1-34) infusion test ${ }^{\mathrm{a}}$} \\
\hline \multicolumn{3}{|l|}{$\begin{array}{l}\text { Urinary cAMP excretion } \\
(\mathrm{nmol} / \mathrm{h})\end{array}$} \\
\hline Basal & 27 & 11 \\
\hline Maximal & 25 & 14 \\
\hline \multicolumn{3}{|l|}{ Urinary phosphate/creatine } \\
\hline Basal & 0.65 & NA \\
\hline Maximal & 1.13 & NA \\
\hline $\begin{array}{r}\text { Serum } \mathrm{T} 4(\mu \mathrm{g} / \mathrm{dl})(\text { normal } \\
\quad \text { range, } 5.1-12.8 \mu \mathrm{g} / \mathrm{dl})\end{array}$ & 9.3 & 6.5 \\
\hline $\begin{array}{l}\text { Serum T3 }(\mathrm{ng} / \mathrm{dl})(\text { normal } \\
\text { range, } 109-215 \mathrm{ng} / \mathrm{dl})\end{array}$ & 243.2 & 155 \\
\hline $\begin{array}{l}\text { TSH level after TRH } \\
\text { stimulation }(\mu \mathrm{U} / \mathrm{ml}) \\
\text { (normal range, } \\
\text { basal TSH; } 0.34-3.5 \mu \mathrm{U} / \mathrm{ml} \text {, } \\
\text { peak TSH; } 15-35 \mu \mathrm{U} / \mathrm{ml} \text { ) }\end{array}$ & $2.5 \rightarrow 21.5$ & $7.8 \rightarrow 45.8$ \\
\hline
\end{tabular}

NA, Not available; PTH, parathyroid hormone; TRH, thyroidstimulating hormone (TSH) releasing hormone; T4, thyroxine; T3, triiodothyronine

${ }^{a}$ PTH infusion test was performed using bolus synthetic PTH-(1-34), at $100 \mathrm{U} / \mathrm{m}^{2}$. Basal levels are the mean urinary cyclic (c)AMP $(\mathrm{nmol} / \mathrm{h})$ and urinary phosphate-to-creatine ratio for two urine samples taken in the $2 \mathrm{~h}$ before the administration of PTH. After PTH infusion, urine samples were collected at the 1-h intervals for $3 \mathrm{~h}$, and the maximum cAMP and phosphate/creatinine concentrations achieved were recorded

${ }^{\mathrm{b}}$ This value was determined by radioimmunoassay (Yamasa Shoyu, Tokyo Japan; normal range, $180-420 \mathrm{pg} / \mathrm{ml}$ ) 
level was $2.5 \mu \mathrm{U} / \mathrm{ml}$ (normal range, $0.34-3.5 \mu \mathrm{U} / \mathrm{ml}$ ). His serum thyroxine (T4), was $9.3 \mu \mathrm{g} / \mathrm{dl}$ (normal range, 5.1$12.8 \mu \mathrm{g} / \mathrm{dl}$ ), serum triiodothyronine (T3) was $243.2 \mathrm{ng} / \mathrm{dl}$ (normal range, 109-215ng/dl) (Table 1), serum free T4 was $1.2 \mathrm{ng} / \mathrm{dl}$ (normal range, $0.8-2.1 \mathrm{ng} / \mathrm{dl}$ ), and serum free $\mathrm{T} 3$ was $3.8 \mathrm{pg} / \mathrm{ml}$ (normal range, $2.7-5.9 \mathrm{pg} / \mathrm{ml}$ ). Basal luteinizing hormone (LH) and follicle stimulating hormone (FSH) levels were $0.25 \mathrm{mIU} / \mathrm{ml}$ and $2.2 \mathrm{mIU} / \mathrm{ml}$, respectively. TSH response after TSH releasing hormone (TRH) was normal (Table 1). After LH-releasing hormone (RH) stimulation, LH and FSH increased to $4.2 \mathrm{mIU} / \mathrm{ml}$, and $12.5 \mathrm{mIU} / \mathrm{ml}$, respectively. Based on these clinical and endocrinological findings, he was diagnosed as having PHPIa. He is now being treated with $1 \alpha$-hydroxyvitamin D3, and his serum calcium level remains normal.

(A)

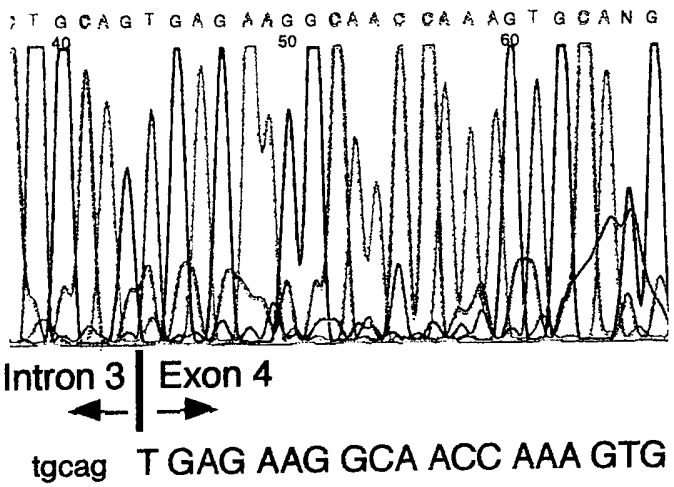

Wild type sequence

(B)
Patient 2

The patient is a Japanese woman who is now aged 36 years, she has a regular menstrual cycle. There is no family history of PHP-Ia and PPHP. At the age of 8 , she was admitted to Hokkaido University Hospital because of seizures, which had occurred for at least 2 years. Her height and body weight at that time were $114.6 \mathrm{~cm}(-1.86 \mathrm{SD}$ for a normal Japanese girl) and $32.3 \mathrm{~kg}$, respectively. Her face was round. Her mental development was mildly retarded. X-Ray films of the hands showed stubby metacarpal bones. Her serum calcium level was $6.1 \mathrm{mg} / \mathrm{dl}$, and serum phosphorus was $7.3 \mathrm{mg} / \mathrm{dl}$. Serum PTH level was high, and PTH stimulation did not increase cAMP excretion (Table 1). At that time, hypothyroidism was also diagnosed, because of low $\mathrm{T} 4$,

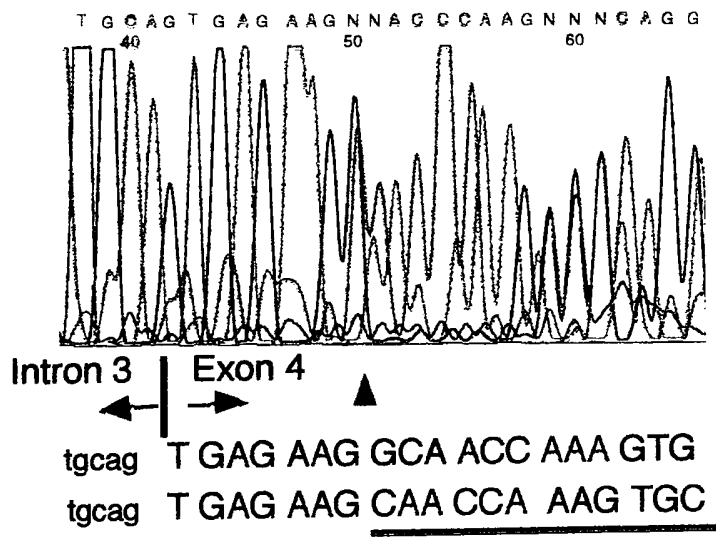

Patient 1

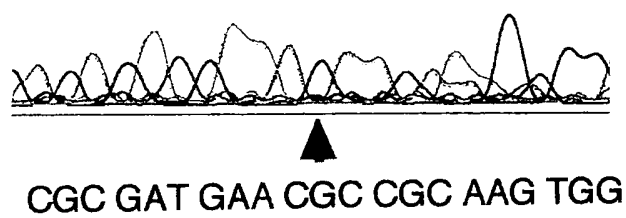

Wild type sequence

Fig. 2A,B. Mutations in the $G s \alpha$ gene in our patients. A Part of the sequence of intron 3 and exon 4 in patient 1. Arrowhead indicates a heterozygous $\mathrm{G}$ base deletion in codon 88 . Note the double bands after the mutation site (underline). B Sequence analysis of exon 9 in patient
2 revealed a heterozygous substitution of $\mathrm{A}$ for $\mathrm{G}$, associated with an amino-acid substitution (R231H). Arrowheads for patient 2 and wild type sequences indicate the mutation site 
elevated basal TSH, and an exaggerated response of the TSH level after TRH stimulation (Table 1). Based on these findings, she was diagnosed as having PHP-Ia.

\section{Methods}

DNA analysis was approved by the institutional review board, and informed consent for DNA analysis was obtained from the adoptive parents of patient 1 and from parents of patient 2. The exons and the intron/exon boundaries in the $G s \alpha$ gene, containing 13 exons, were analyzed by polymerase-chain-reaction (PCR) and direct sequencing with specific primers as reported previously, (Kozasa et al. 1988; Shapira et al. 1996). Amplitaq-Gold (Perkin-Elmer and Applied Biosystems, Foster City, CA, USA) and its standard buffer were used in all reactions. All exons were amplified by PCR under the following conditions; initial denaturation at $95^{\circ} \mathrm{C}$ for $7 \mathrm{~min}$, followed by 30 cycles at $94^{\circ} \mathrm{C}$ for $1 \mathrm{~min}, 58^{\circ} \mathrm{C}$ for $1 \mathrm{~min}$, and $72^{\circ} \mathrm{C}$ for $1 \mathrm{~min}$. The amplified products were directly purified with Wizard PCR prep columns (Promega, Madison, WI, USA), and the purified PCR products were sequenced with an automated sequencer (model 373A; Applied Biosystems, Foster City, CA, USA) according to the manufacturer's protocol (Nakae et al. 1996).

\section{Results}

In patient 1 , a heterozygous mutation of one $\mathrm{G}$ base deletion at codon 88 in exon 4 was identified (Fig. 2A). This frameshift mutation introduces a premature stop codon 30 bases downstream in exon 4 . Sequence analysis of exon 9 in patient 2 revealed a heterozygous substitution of $A$ for $G$ (Fig. 2B). This base change, associated with an amino-acid substitution $(\mathrm{R} 231 \mathrm{H})$, was previously reported in one pedigree with PHP-Ia (Farfel et al. 1996). DNA from the parents of each of the two patients was not available, and, thus, we were not able to determine the transmission of these mutations.

\section{Discussion}

So far, 22 different loss-of-function mutations of the Gsa gene have been described (Fig. 1) (Ahmed et al. 1998; Farfel et al. 1996; Fischer et al. 1998; Iiri et al. 1994; Miric et al. 1993; Oude-Luttikhuis et al. 1994; Pattern et al. 1990; Schwindinger et al. 1994; Shapira et al. 1996; Warner et al. 1997, 1998; Weinstein et al. 1990, 1992; Yu et al. 1995, 1999). Of these mutations, the four-base deletion in exon 7 was identified most frequently ( $35 \%)$; however, this mutation has not yet been reported in Japanese patients. In this study, one mutation (delG at codon 88) was new, and the other mutation $(\mathrm{R} 231 \mathrm{H})$ had been reported previously, suggesting that the molecular defect of PHP-Ia may be heterogeneous in Japan. Further analysis of Japanese patients with PHP-Ia is required to determine the frequency of the mutation of the $G s \alpha$ gene.

In our study, DNA from parents was not available, and thus, we could not determine whether these mutations were transmitted maternally or paternally. As mentioned, it has been thought that the Gsa gene is imprinted. In this context, it is important to determine the pattern of the transmission of the mutations in PHP-Ia and PPHP patients.

The one-base deletion $(\mathrm{G})$ in exon 4 of patient 1 produces a premature stop codon and may lead to the truncated protein. Therefore, this mutation may be the cause of the disease. Concerning the R231H mutation, Farfel et al. (1996) reported the identical mutation in three patients with PHP-Ia. According to their in-vitro study, this mutant Gs protein impaired the responsiveness of $G s \alpha$ to receptor stimulation, leading to PTH resistance. These findings of Farfel et al. (1996) confirm that the disease in patient 2 is caused by the R231H mutation.

Finally, Yu et al. (1999) have reported that the TSH resistance in PHP-Ia patients progresses with age. Patient 1 showed a normal serum level of TSH at the age of 7 years, but patient 2 had a low T4 level, elevated TSH level, and exaggerated TSH response to TRH at the age of 8 years. These findings indicate that careful follow-up of thyroid function should be done in PHP-Ia patients.

In conclusion, we identified two mutations in two Japanese PHP-Ia patients, and we note that genetic analysis of $G s \alpha$ will help to supplement the clinical evaluation of some patients and their families, particularly as the disease may not be fully penetrant.

\section{References}

Ahmed SF, Dixon PH, Bonthron DT, Stirling HF, Barr DG, Kelnar CJ, Thakker RV (1998) GNAS1 mutational analysis in pseudohypoparathyroidism. Clin Endocrinol 49:525-531

Farfel Z, Brickman AS, Kaslow HR, Brothers VM, Bourne HR (1980) Defect of receptor-cyclase coupling protein in pseudohypoparathyroidism. N Engl J Med 303:237-242

Farfel Z, Iiri T, Shapira H, Roitman A, Mouallem M, Bourne HR (1996) Pseudohypoparathyroidism, a novel mutation in the $\alpha$ contact region of $G s \alpha$ impairs receptor stimulation. J Biol Chem 271:19653-19655

Fischer JA, Egert F, Werder E, Born W (1998) An inherited mutation associated with functional deficiency of the alpha-subunit of guanine nucleotide-binding protein Gs in pseudo and pseudopseudohypoparathyroidism. J Clin Endocrinol Metab 83:935-938

Hayward BE, Moran V, Strain L, Bonthron DT (1998) Bidirectional imprinting of a single gene: GNAS1 encodes maternally, paternally, and biallelically derived proteins. Proc Natl Acad Sci USA 95:1547515480

Kozasa T, Itoh H, Tsukamoto T, Kaziro Y (1988) Isolation and characterization of the human Gs alpha gene. Proc Natl Acad Sci USA 85:2081-2085

Iiri T, Herzmark P, Nakamoto JM, Van-Dop C, Bourne HR (1994) Rapid GDP release from $G s \alpha$ in patient with gain and loss of endocrine function. Nature 371:164-168

Levine MA (1999) Pseudohypoparathyroidism: from bedside to bench and back. J Bone Miner Res 14:1255-1260

Marguet C, Mallet E, Basuyau JP, Martin D, Leroy M, Brunelle $P$ (1997) Clinical and biological heterogeneity in pseudohypoparathyroidism syndrome. Horm Res 48:120-130 
Miric A, Vechio JD, Levine MA (1993) Heterozygous mutations in the gene encoding the alpha-subunit of the stimulatory $\mathrm{G}$ protein of adenylyl cyclase in Albright hereditary osteodystrophy. J Clin Endocrinol Metab 76:1560-1568

Nakae J, Tajima T, Kusuda S, Kohda N, Okabe T, Shinohara N, Kato M, Murashita M, Mukai T, Imanaka K, Fujieda K (1996) Truncation at C-terminus of the DAX-1 protein impairs its biological actions in patients with X-linked adrenal hypoplasia congenita. J Clin Endocrinol Metab 81:3680-3685

Nakamoto JM, Samdstrorm AT, Brickman AS, Christenson RA, Van Dop C (1998) Pseudohypoparathyroidism type Ia from maternal but not paternal transmission of a Gs $\alpha$ gene mutation. Am J Med Genet 77:261-267

Oude-Luttikhuis NEM, Wilson LC, Leonard JV, Trembath RC (1994) Characterization of a de novo 43-bp deletion of Gs $\alpha$ gene (GNAS1) in Albright hereditary osteodystrophy. Genomics 21:451457

Pattern JL, Johns DR, Valle D, Eli C, Gruppuso PA, Steels G, Smallwood PM, Levine MA (1990) Mutation in the gene encoding the stimulatory $G$ protein of adenylate cyclase in Albright's hereditary osteodystrophy. N Engl J Med 322:1412-1419

Schwindinger WF, Miric A, Zimmerman D, Levine MA (1994) A novel Gs alpha mutant in a patient with Albright hereditary osteodystrophy uncouples cell surface receptors from adenylyl cyclase. J Biol Chem 269:25387-25391

Shapira H, Mouallem M, Shapiro MS, Weinstein Y, Farfel Z (1996) Pseudohypoparathyroidism type Ia: two new heterozygous frameshift mutations in exon 5 and 10 of the Gs alpha gene. Hum Genet 97:73-75

Spiegel AM (1999) Hormone resistance caused by mutations in G proteins and G-coupled receptors. J Clin Pediatr Endocrinol Metab 12:303-309
Warner DR, Gejman PV, Collins RM, Weinstein LS (1997) A novel mutation adjacent to the switch III domain of $G$ ( $S$ alpha) in a patient with pseudohypoparathyroidism. Mol Endocrinol 11:17181727

Warner DR, Weng G, Yu S, Matalon R, Weinstein LS (1998) A novel mutation in the switch 3 region of Gs alpha in a patient with Albright hereditary osteodystrophy impairs GDP binding and receptor activation. J Biol Chem 273:23976-23983

Weinstein LS, Gejman PV, Friedman E, Kadowaki T, Collins RM, Gershon ES, Spiegel AM (1990) Mutations of the Gs alpha subunit gene in Albright's hereditary osteodystrophy detected by denaturing gradient gel electrophoresis. Proc Natl Acad Sci USA 87:82878290

Weinstein LS, Gejman PV, Mazancorte P de, American N, Spiegel AM (1992) A heterozygous 4-bp deletion mutation in the Gsa gene (GNAS1) in a patient with Albright hereditary osteodystrophy. Genomics 13:1319-1321

Weinstein LS, Yu S, Ecelbarger CA (2000) Variable imprinting of the heterotrimeric $\mathrm{G}$ protein (Gs) alpha-subunit with different segment of the nephron. Am J Renal Physiol 278:507-514

Wilson LC, Oude-Luttikhuis ME, Clayton PT, Fraser WD, Trembath RC (1994) Parental origin of Gs $\alpha$ gene mutations in Albright's hereditary osteodystrophy. J Med Genet 31:835-839

Yu D, Yu S, Schuster V, Kruse K, Clericuzo CL, Weinstein LS (1999) Identification of two novel deletion mutations within the Gs alpha gene (GNAS1) in Albright hereditary osteodystrophy. J Clin Endocrinol Metab 84:3254-3259

Yu S, Yu D, Hainline BE, Brener JL, Wilson KA, Wison LC, OudeLuttikhuis ME, Trembath RC, Weinstein LS (1995) A deletion hotspot in exon 7 of the Gs aplha gene (GNAS1) in patients with Albright hereditary osteodystrophy. Hum Mol Genet 1995 10:20012002 